\title{
Differences Effect of Direct and Indirect Learning Methods on Increasing Triple Jump Capability in Male Students of Xi Students of Sma Negeri I Polokarto Sukoharjo
}

\author{
Koko Prasetyo
}

Faculty of Teacher Training and Education, University of Veteran Bangun Nusantara, Indonesia Email: kokoprasetyo_15@yahoo.co.id

http://dx.doi.org/10.18415/ijmmu.v5i6.515

\begin{abstract}
This study aims to determine: 1) The difference between the effect of direct and indirect learning methods to an increase in male's triple jump at the class XI student of SMA Negeri I Polokarto Sukoharjo; 2) Learning that has a better effect between direct and indirect learning on the increase in triple jumps in male students of class XI student of SMA Negeri 1 Polokarto Sukoharjo. The research method used is the experimental method, the namely experimental activity which begins with giving treatment to the subject which ends with a form of test to determine the effect of the treatment that has been given. The sampling technique used is random sampling. The population in this study were male students of class XI of SMA Negeri 1 Polokarto Sukoharjo in the 2017/ 2018 academic year, totaling 71 students and then drawn with a random sampling technique to obtain 30 samples. Data analysis techniques were carried out by normality and homogeneity tests, to fulfill the assumptions about the results of the study conducted a different test. Based on the results of the study obtained the following conclusions: 1) There is a significant difference between the direct and indirect learning approaches to the ability of triple jump in male students of class XI of SMA Negeri 1 Polokarto Sukoharjo in academic year 2011/ 2012, with a calculated value $t_{\text {count }}$ is 2,229 and $t_{\text {table }}$ is 2.145 with a significance level of $5 \%$;2) Triple jump learning with the indirect learning approach has a better effect than the direct learning approach to the ability of triple jump in male students of class XI of SMA Negeri 1 Polokarto Sukoharjo in the academic year 2017/2018. Group 1 (direct learning) has an increase of $2.491 \%$. While group 2 (indirect learning) has an increasing percentage of $6.820 \%$.
\end{abstract}

Keywords: Triple Jump; Direct Learning; Indirect Learning

\section{Introduction}

Physical education is an integral part of overall education through various physical activities that aim to develop individuals organically, neuromuscular, intellectually and emotionally. Physical activity in education has got a touch of didactic- methodology so that it can be directed at efforts to achieve the learning goals that it wants to achieve. To achieve the basic competencies of physical education, the basic material of physical education must be taught to students. The 2004 curriculum explains that, "The main material of physical education is grouped into six aspects, namely: 1) play and sports; 2) development 
activities; 3) self-test/ gymnastics; 4) rhythmic activity; 5) aquatic and 6) outside activities school" (Ministry of National Education., 2004: 19-20).

Physical activity through physical education learning must get a touch of didactic action - the teacher's method so that it becomes an educational tool that can help children develop their overall personality. Physical education has a very noble goal can be achieved by paying attention to many other supporting factors such as teachers, students, facilities, methods, and appropriate learning approaches. The learning approach must be suitable for use in learning theory and practice skills, this is done solely to improve the effectiveness and efficiency of the learning process. The learning process can be effective if changes in behavior that occur in students at least reach the optimal level. Students' attitudes and behavior can be formed by increasing student participation actively in all forms of sports activities. Physical education activities have the characteristic of borrowing sports activities to achieve the desired educational goals.

Athletics is one of the elements of physical education and health and is a component of overall education that prioritizes physical activity, fostering a healthy life and harmonious, harmonious and balanced physical, mental, social and emotional development. Athletics itself is a sport that has an important role to support the development of the child's movement towards the athletic movement. This is in the opinion of Aip Syarifudin (1992: 18) that "the formation of basic movements, especially the formation of basic athletic movements is an encouragement in an effort to divert the forms of movement that children have before entering school into basic forms of movement that lead to athletics". Children's basic ability can be improved through athletic learning. Therefore, athletics is one of the sports that must be taught in schools.

The triple jump is one of the prestigious numbers in athletic sports. The triple jump is a jump movement that is carried out with a prefix followed by jumping with three jumps. Each of which is hop, steep, jump. In the learning process, there are many teachers applying traditional methods that resulting in boredom in students and the monotonous of the learning process in students. So many students are not able to receive lessons athletics triple jump properly. If this learning is carried out maximally, the maximum results will be obtained. Learning contains understanding, how the teacher teaches something to the students in addition to that also occurs events how learners learn it. (Sukintaka., 2004: 55). In learning, there are components of students who carry out the learning process and the teacher as the giver of learning material (teaching). In the implementation of learning, there is an interaction between the teacher (teacher) and the learner (student), where the interaction is an educational interaction.

Teaching is an activity carried out by the teacher or instructor to provide changes to students. Nana Sudjana (2000: 29) states that: "Teaching is essentially a process, namely the process of arranging, organizing the environment around students so that it can cause and encourage students to do the learning process". Whereas according to Rusli Lutan (1988: 381) states that, "teaching is a set of intentional activities by someone who has more knowledge or skills than those taught". The approach is defined as our starting point or point of view of the learning process. The effectiveness of teaching is largely determined by the teaching approach chosen by the teacher on the basis of the teacher's knowledge of the nature of the skills or the task of learning that students will learn.

Learning with a direct approach is learning skills by providing technical material that is directly learned. Rusli Lutan (1988: 419) argues that "learning with a direct approach is learning where the teacher or trainer teaches the actual technique directly". Direct learning is a learning approach model that can help students to learn or master basic skills. By using the approach model is a way of approaching the provision of training material from the beginning, the player is directed to practice the whole movement being studied. In this case, it takes skills, activeness, the creativity of teachers and students to be enthusiastic, disciplined, and earnest. 
The learning of triple jumping with a direct approach is a learning that directly provides the basic material of basic jumping techniques that are actually in accordance with the actual triple jump rules. That gives the material the basic techniques for triple jump is made from the initial point to do away with the direct techniques triple jump (hop, step, jump) and ends. In the early stages of learning students usually, make technical mistakes and less coordinated movement patterns. Gradually the basic techniques for triple jump will be controlled properly after participating in learning activities repeatedly.

Learning with an indirect approach is learning skills that are preceded by giving material movement techniques rather than the actual ones. According to Rusli Lutan (1988: 418) that, "learning with an indirect approach is a teaching approach where the teacher or trainer prepares a training plan carefully in a series of logical sequences before the actual technique is taught". In the early stages, students are given material by doing movements similar to repeated technical movements.

The indirect learning approach is the way students learn through step by step with the learning process in different forms, meaning learning basic movements starting from easy movements to difficult movements, from low movements to high movements, and from simple movements to complex movements. In this case, it takes the craft, discipline, skills, and creativity of the teacher in giving motivation to students to make movements.

The material given in the early stages is the basic movements that are relevant to the triple jump movement. The movement starts with a simple movement that resonates with the movement of the triple jump, then leads to the actual triple jump movement. The basic movement provided in the learning of triple jumping with indirect approaches is the start movement, the movement of the convergence continues the triple jump technique (hop, step, jump), end of the landing movement and so on. The basic movements taught may increase the mastery of the basic jump technique of the jump.

Based on the issues raised, this research has the objective to determine: 1) The difference between the effect of direct learning method with indirectly to an increase in male's triple jump at the class XI student of SMAN I Polokarto Sukoharjo; 2) Learning that has a better effect between direct and indirect learning on the increase in triple jumps in male students of class XI of SMA Negeri 1 Polokarto Sukoharjo. Therefore, this study took the title "The Differences Effect of Direct and Indirect Learning Methods on Increasing Triple Jump Capability in Male Students of XI Students of SMA Negeri I Polokarto Sukoharjo"

\section{Methodology}

The type of research used is experimental research. The basis of the use of experimental research is the experimental activity which begins with giving treatment to the subject which ends with a form of test to determine the effect of the treatment that has been given. While the design used is Pretest-Posttest Design, Sugiyanto (1995: 21). The division of the experimental group is based on the results of the test of the triple jump on the initial test.

After the results of the initial test are ranked, then the subjects who have the equivalent ability are placed in groups 1 (K1) and group 2 (K2). Thus the two groups before being treated were the same group. If in the end there is a difference, then this is caused by the effect of the treatment given. Division of groups in this study by means of pairing ordinal.

The technique of collecting data used in this research is the data of increase capability of the triple jump. Triple jump data to find out the rise of triple jumps as a result of the treatment provided in direct and indirect learning models. 
All of the data provided in this study, as stated above, were obtained through tests and measurements of the ability of triple jumps using the test of triple jump ability. The test was carried out 2 times, namely the initial test before treatment and the final test after being treated. Before the data analysis technique was carried out before the analysis prerequisite test, the analysis prerequisite test in this study included the normality test and homogeneity test.

Data analysis in this study was carried out by a different test from Sutrisno Hadi (1995: 457) as follows:

$$
t=\frac{\sum M_{d}}{\sqrt{\frac{\sum d^{2}}{N(N-1)}}}
$$

Explanation:

$\mathrm{t}=$ Difference test value

md $\quad=$ Mean difference from pair

$\sum d^{2}=$ The sum of the squared deviations of each sample from the mean difference

$\mathrm{N} \quad=$ Number of pairs

To calculate the percentage increase in triple jump capability between the initial test and the final test, use the following formula:

The Percentage Increase $=\frac{\text { mean different }}{\text { Mean pretest }} \times 100 \%$

\section{Result and Discussion}

The results of the initial test reliability test of the triple jump ability in the study is illustrated in Table 1.

Table 1 Summary of test results reliability of initial test and final test

\begin{tabular}{lcc}
\hline Test & Reliability & Category \\
\hline Initial test of the triple jump ability & 0,7917 & Sufficient \\
The final test of the triple jump ability & 0,9592 & Very High \\
\hline
\end{tabular}

To interpret the test reliability coefficient using the guidelines of the correlation coefficient table is shown in Table 2, as quoted Mulyono Book Walter B. (1992: 15). 
Table 2 Range of reliability

\begin{tabular}{lccc}
\hline Category & Validity & Reliability & Objectivity \\
\hline Very High & $0,80-1,0$ & $0,90-1,0$ & $0,95-1,0$ \\
High & $0,70-0,79$ & $0,80-0,89$ & $0,85-0,94$ \\
Sufficient & $0,50-0,69$ & $0,60-0,79$ & $0,70-0,84$ \\
Low & $0,30-0,49$ & $0,40-0,59$ & $0,50-0,69$ \\
Not Significant & $0,00-0,29$ & $0,00-0,39$ & $0,00-0,49$ \\
\hline
\end{tabular}

The normality test of the data in this study was used by the Lilliefors method. The results of the data normality test performed on the results of the initial tests in groups 1 and 2 are shown in Table 3 .

Table 3 Summary of data normality test results initial test

\begin{tabular}{lccccc}
\hline Group & $\mathrm{N}$ & Mean & $\mathrm{SD}$ & $\mathrm{L}_{\text {count }}$ & $\mathrm{L}_{\mathrm{t} 5 \%}$ \\
\hline K1 & 15 & 8,11 & 0,58 & 0,174 & 0,220 \\
K2 & 15 & 7,98 & 0,63 & 0,135 & 0,220 \\
\hline
\end{tabular}

Based on the results of the normality test of the initial test data conducted in group $1\left(\mathrm{~K}_{1}\right)$ obtained the value of $\mathrm{L}_{\text {count }}=0.174$ Value it is smaller than the rejection limit at a significant level of $5 \%$, which is 0.220 . Thus it can be concluded that the data in group $1\left(\mathrm{~K}_{1}\right)$ includes the normal distribution. While the results of the normality test conducted in group $2\left(\mathrm{~K}_{2}\right)$ obtained a value of $\mathrm{L}_{\text {count }}=0.135$, it was also smaller than the limit of rejection of the null hypothesis at a significant level of 5\%, which is 0.220. Thus it can be concluded that the data in group $2\left(\mathrm{~K}_{2}\right)$ are normally distributed.

Table 4 Summary of the normality test results of final test data

\begin{tabular}{cccccc}
\hline Group & $\mathrm{N}$ & Mean & SD & $\mathrm{L}_{\text {count }}$ & $\mathrm{L}_{\mathrm{t} 5 \%}$ \\
\hline K1 & 15 & 8,31 & 0,53 & 0,205 & 0,220 \\
K2 & 15 & 8,52 & 0,57 & 0,102 & 0,220 \\
\hline
\end{tabular}

Based on the results of the normality test data final test conducted in group $1\left(\mathrm{~K}_{1}\right)$ the value of $\mathrm{L}_{\text {count }}=0.205$. This value is smaller than the rejection limit number at a significant level of $5 \%$, which is 0.220 . Thus it can be concluded that the data in group $1\left(\mathrm{~K}_{1}\right)$ includes the normal distribution. While the results of the normality test conducted in group $2\left(\mathrm{~K}_{2}\right)$ obtained $\mathrm{L}_{\text {count }}=0.102$, it was also smaller than the null hypothesis rejection rate at a significant level of $5 \%$ which is 0.220 . Thus it can be concluded that the data in group $2\left(\mathrm{~K}_{2}\right)$ are normally distributed.

The homogeneity test was intended to determine the similarity of the variance between the two groups. If the two groups have the same variance, then if later the two groups have differences, then the difference is due to differences in average abilities. The homogeneity test results between groups 1 and 2 are shown in Table 5. 
Table 5 Summary of homogeneity test results initial test data

\begin{tabular}{lllll}
\hline Group & $\mathrm{N}$ & $\mathrm{SD}^{2}$ & $\mathrm{~F}_{\text {count }}$ & $\mathrm{F}_{\mathrm{t} 5 \%}$ \\
\hline K 1 & 15 & 0,337 & 0,853 & 2,484 \\
K 2 & 15 & 0,396 & & \\
\hline
\end{tabular}

Based on the test results homogeneity of the initial test data conducted obtained $\mathrm{F}_{\text {count }}=0.853$. Whereas with $\mathrm{db}=14$ versus 14 , then the number $\mathrm{F}_{\mathrm{t} 5 \%}=2.484$, it turns out that the value of $\mathrm{F}_{\text {count }}$ is 0.853 is smaller than $F_{t 5 \%}=2,484$. Because $F_{\text {count }}<F_{\text {table } 5 \%}$, then the null hypothesis is accepted. Thus, it can be concluded that group $1\left(\mathrm{~K}_{1}\right)$ and group $2\left(\mathrm{~K}_{2}\right)$ have homogeneous variations.

Table 6 Summary of homogeneity test results for final test data

\begin{tabular}{lcccc}
\hline Group & $\mathrm{N}$ & $\mathrm{SD}^{2}$ & $\mathrm{~F}_{\text {count }}$ & $\mathrm{F}_{\mathrm{t} 5 \%}$ \\
\hline K 1 & 15 & 0,281 & 0,873 & 2,484 \\
K 2 & 15 & 0,322 & & \\
\hline
\end{tabular}

Based on the results of the final test homogeneity test data obtained $\mathrm{F}_{\text {count }}=0.873$. Whereas with $\mathrm{db}=14$ versus 14 , then the number $\mathrm{F}_{\mathrm{t} 5 \%}=2.484$, it turns out that the value of $\mathrm{F}_{\text {count }}$ is 0.873 is smaller than $\mathrm{F}_{\mathrm{t} 5 \%}=2,484$. Because $\mathrm{F}_{\text {count }}<\mathrm{F}_{\text {table } 5 \%}$, then the null hypothesis is accepted. Thus it can be concluded that group $1\left(\mathrm{~K}_{1}\right)$ and group $2\left(\mathrm{~K}_{2}\right)$ have homogeneous variations.

After treatment, group 1 was treated with direct triple jump learning and group 2 was given triple jump learning with an indirect approach, then a multiplication test was carried out. Test the difference in this research results are as follows:

\section{The result of differences in the initial test and final test in group 1 is shown in Table 7.}

Table 7 Test results difference test early and test end at group 1

\begin{tabular}{lcccc}
\hline Group & $\mathrm{N}$ & Mean & $\mathrm{T}_{\text {count }}$ & $\mathrm{t}_{\text {table } 5 \%}$ \\
\hline Initial test & 15 & 8,11 & 5,747 & 2,145 \\
Final test & 15 & 8,31 & & \\
\hline
\end{tabular}

Based on the results of the calculation it is known that $t_{\text {count }}=5.747$. With $d b=14$ at $a$ significance level of $5 \%$, the value of $t_{\text {table }}=2.145$. The comparison shows that $t_{\text {count }}>t_{\text {table }}$ means the null hypothesis is rejected. Thus concluded that there are differences in the ability of beginning and end of group 1 .

\section{The test results of initial tests and the final test in group 2 are shown in Table 8.}

Table 8 Preliminary test results test and final test in group 2

\begin{tabular}{lcccc}
\hline Group & $\mathrm{N}$ & Mean & $\mathrm{T}_{\text {count }}$ & $\mathrm{t}_{\text {table 5\% }}$ \\
\hline Initial test & 15 & 7,98 & \multirow{2}{*}{15,552} & 2,145 \\
Final test & 15 & 8,52 & & \\
\hline
\end{tabular}


Based on the results of the calculation it is known that $t_{\text {count }}=15,552$. With $\mathrm{db}=14$ at $\mathrm{a}$ significance level of $5 \%$, the value of $t_{\text {table }}=2.145$ is. The comparison shows that $t_{\text {count }}>t_{\text {table }}$ means the null hypothesis is rejected. Thus it was concluded that there were differences in the initial and final abilities in group 2.

\section{The final test results of the difference test between groups 1 and 2 groups were:}

Table 9 Difference of final test results between group 1 and group 2

\begin{tabular}{lcccc}
\hline Group & $\mathrm{N}$ & Mean & $\mathrm{T}_{\text {count }}$ & $\mathrm{t}_{\text {table 5\% }}$ \\
\hline Initial test & 15 & 8,31 & 22,229 & 2,145 \\
Final test & 15 & 8,52 & & \\
\hline
\end{tabular}

Based on the results of calculations known that $\mathrm{t}_{\text {count }}=2.229$. With $\mathrm{db}=14$ at a significance level of $5 \%$, the value of $t_{\text {table }}=2.145$. The comparison shows that $t_{\text {count }}>t_{\text {table }}$ means the null hypothesis is rejected. Thus it was concluded that there was a difference in the ability of the end of the jump between groups 1 and groups 2 .

\section{Increased Percentage Difference}

Which group has a better percentage increase can be known by calculating the difference in the percentage increase for each group. The difference in the increase in triple jump ability in percent between group 1 and group 2 isshown in Table 10.

Table 10 Ability triple jump between group 1 and group 2

\begin{tabular}{lccccc}
\hline Group & $\mathrm{N}$ & $\begin{array}{c}\text { Mean } \\
\text { Pretest }\end{array}$ & $\begin{array}{c}\text { Mean } \\
\text { Posttest }\end{array}$ & $\begin{array}{c}\text { Mean } \\
\text { Different }\end{array}$ & $\begin{array}{c}\text { Prosentase } \\
\text { Peningkatan }\end{array}$ \\
\hline Group 1 & 15 & 8,11 & 8,31 & 0,20 & $2,491 \%$ \\
Group 2 & 15 & 7,98 & 8,52 & 0,54 & $6,820 \%$ \\
\hline
\end{tabular}

Based on the results of calculating the percentage increase in triple jump ability it is known that group 1 has an increase in triple jump ability of $2.491 \%$. While group 2 has an increase in triple jump ability by $6.820 \%$. Thus, it can be concluded that group 2 has a greater percentage increase in the ability of triple jump than group 1.

\section{Conclusion}

Based on the results of the research and the results of data analysis that has been done, it turns out that the proposed hypothesis is acceptable. Thus, it can be concluded as follows:

1. There is a difference in influence between direct and indirect triple jump learning about the ability of triple jump in male students of class XI of SMA Negeri 1 Polokarto Sukoharjo in the academic year $2017 / 2018$, with a calculated value of 2,229 and a table of 2,145 at a significance level of 5\%. 
2. The learning of triple jump indirectly has the better effect on the ability of triple jump in male students of class XI of SMA Negeri 1 Polokarto Sukoharjo in the school year of 2017/2018, group 1 (the group that received treatment for direct jump learning) had an increase of $2.491 \%$. While group 2 (the group that received the indirect triple jump learning treatment) had an increase of $6.820 \%$.

\section{References}

Adang Suherman, Yudha M. Saputra,Yudha Hendrayana. (2001). Pembelajaran Atletik Pendekatan Permainan dan Kompetisi. Jakarta: Departemen Pendidikan Nasional.

Aip Syarifudin. (1992). Atletik. Jakarta: Departemen Pendidikan dan Kebudayaan Dirjen Dikti Proyek Pembinaan Tenaga Kependidikan.

Magill, Richard A. (1995). Motor Learning Concepts and Applications. Louisiana State University: Wm. C. Brown Communications, Inc.

Nana Sudjana. (2000). Dasar-Dasar Proses Belajar Mengajar. Bandung: Sinar Baru Algensindo.

Samsudin. (2009). Pembelajaran Pendidikan Jasmani Olahraga dan Kesehatan Sekolah Dasar/ MI. Jakarta.

Sugiyanto. (1998). Perkembangan dan Belajar Motorik. Jakarta: Universitas Terbuka. (1995). Metodologi Penelitian. Jakarta: Universitas Terbuka.

Sukintaka. (2004). Teori Pendidikan Jasmani. Filosofi Pembelajaran dan Masa Depan. Yogyakarta.

Rusli Lutan. (1988). Belajar Keterampilan Motorik, Pengantar Teori dan Metode. Jakarta: Departemen Pendidikan dan Kebudayaan Direktorat Jendral Pendidikan Tinggi Proyek Pengembangan Lembaga Pendidikan Tenaga Kependidikan.

Rusli Lutan \& Adang Suherman. (2000). Perencanaan Pembelajaran Penjaskes. Jakarta: Departemen Pendidikan Nasional, Direktorat Jendral Pendidikan Dasar dan Menengah.

Wina Sanjaya. (2010). Perencanaan dan Desain Sistem Pembelajaran. Jakarta: Prenada Media Group.

Harald Muller dan Wolfgang Ritzdorf, __. Lari, Lompat, Lembar Level I. Dialih-bahasakan oleh Suyono Danusyogo. Staf Sekretariat IAAF-RDC: Jakarta.

\section{Copyrights}

Copyright for this article is retained by the author(s), with first publication rights granted to the journal.

This is an open-access article distributed under the terms and conditions of the Creative Commons Attribution license (http://creativecommons.org/licenses/by/4.0/). 